\title{
Application of Factorial Design for Optimization of the Synthesis of Lactulose Obtained from Whey Permeate
}

\author{
Fernanda C. Zimmer, ${ }^{a}$ Aloisio H. P. Souza, ${ }^{b}$ Ana F. C. Silveira, ${ }^{a}$ Maristela R. Santos, ${ }^{a}$ \\ Makoto Matsushita, ${ }^{c}$ Nilson E. Souza ${ }^{c}$ and Angela C. Rodrigues ${ }^{*, a}$
}

\author{
${ }^{a}$ Universidade Tecnológica Federal do Paraná (UTFPR), Av. Brasil, 4232, 85884-000 Medianeira-PR, Brazil \\ ${ }^{b}$ Instituto Federal do Mato Grosso do Sul (IFMS), Rua Salime Tanure, s/n, Santa Tereza, \\ 79400-000 Coxim-MS, Brazil
}

${ }^{c}$ Universidade Estadual de Maringá (UEM), Av. Colombo, 5790, 87020-900 Maringá-PR, Brazil

\begin{abstract}
There is a great interest in developing suitable alternatives for the utilization of whey, a by-product from cheese production that contains high concentration of lactose. These alternatives allow the transformation of whey into several products, reducing its environmental impact and providing gains to the dairy industry through the development of new products. The goal of this study was to optimize the synthesis of lactulose from the permeate of bovine whey. The response surface methodology (RSM) was used to investigate the effect of two parameters, time of reaction (90, 135 and $180 \mathrm{~min}$ ) and isomerization type (sodium sulfite, boric acid and $\beta$-galactosidase enzyme), aiming to obtain the highest reaction yield. According to the response surface and desirability function, the best experimental conditions for lactulose synthesis (where it was obtained $50.06 \mathrm{~g}$ of lactulose per $100 \mathrm{~g}$ of whey powder) consisted of a reaction time of $180 \mathrm{~min}$ with the use of enzymatic isomerization.
\end{abstract}

Keywords: prebiotics, experimental design, reuse of industrial by-products

\section{Introduction}

Lactulose (4-O- $\beta$-D-galactopyranosyl-D-fructose) is a ketosis, which is a semi-synthetic disaccharide, consisting of a fructose and a galactose molecule. ${ }^{1-5}$ It is slightly sweeter than lactose and can be used to replace part of the sucrose in some food products. ${ }^{6}$ In addition, lactulose is a functional nutrient with great added value because it is a prebiotic disaccharide that can be widely applied in food and pharmaceutical products.

Lactulose is chemically produced by lactose isomerization through Lobry de Bruyn-Alberda van Ekenstein transformation, using catalysts such as sodium and calcium hydroxides, sulfites, aluminates, phosphates and borates. ${ }^{7}$ The chemical process includes subsequent purification steps to remove high concentrations of by-products. An alternative method for obtaining high purity lactulose is bioconversion; the application of this process to convert lactose into lactulose has been studied using enzymes. ${ }^{8}$

*e-mail: angelac.utfpr@gmail.com
Lactulose has several applications in medicine, including uses in chronic constipation, hepatic encephalopathy, colon carcinogenesis and ischemic stroke. The food industry uses lactulose in infant nutrition, yogurt, fermented soybean extract, fermented skimmed milk and also as a food additive. The European Commission (No. 575/2011) ${ }^{9}$ has approved the use of lactulose as a food ingredient in animal feed production due to several beneficial properties. The main benefits are: reducing antibiotic consumption, presenting prebiotic action, increasing mineral absorption, hyperglycemic and hypocholesterolemic effects, helping to prevent and reduce urinary tract infection, and also reducing intestinal transit time.

Whey is a by-product of cheese production, is a low-cost raw material and has a high concentration of lactose. Large amounts of the whey produced by the dairy industry are used for animal feed and as a food ingredient. ${ }^{10}$

However, about $30 \%$ of the annual worldwide production of whey are still discarded, and are considered as a water pollutant due to its high chemical and biochemical oxygen demand. ${ }^{11,12}$ The availability and cost-effective use of whey has become very important for dairy industries. 
In addition, environmental and economic concerns require the transformation of serum into value-added products.

Whey proteins are its most valuable constituents, and some industries use them as whey protein concentrates. These are obtained by pre-concentration using ultrafiltration followed by spray drying. ${ }^{13}$

Thus, ultrafiltration allows changes in component concentrations and ratios due to the selective retention of proteins and other colloidal materials, the partial retention of nitrogen compounds and the permeation of lactose and mineral salts.

However, the use of whey to obtain whey protein concentrates produces another by-product, the whey permeate, which is also a concern due to its polluting potential.

This by-product is rich in lactose and could be submitted to a spray drying process to obtain powdered lactose for commercial use. However, the atomization of whey permeate becomes unfeasible for industries due to the low commercial value of lactose and the loss of product by crystallization during storage, where part of the amorphous lactose becomes substituted with crystalline lactose. ${ }^{14}$

Besides, lactose is little used in the food industry because of its low sweetening power and low solubility. ${ }^{15-17}$ However, it can be used as added-value ingredient in many food products, including dairy products, meats, breads, pastries, snacks and beverages, mainly because of its recently discovered functional and bioactive properties. ${ }^{15}$

The concentration of lactose in milk and whey varies widely among species. Thus, the lactose content of bovine milk varies with race, other individual factors and especially with the lactation stage of the animal. ${ }^{18}$ Despite this variation, lactose is considered the main component of dairy products on a dry basis, and the most abundant solid in the serum, reaching $70 \%$ in whey powder. ${ }^{19}$

Besides, in optimization experiments studies, the optimal conditions can be achieved by varying the factors, each one in a different experiment. ${ }^{20}$ However, this kind of approach involves a larger number of experiments, may not guarantee the determination of optimal conditions and does not present the interaction effect of all the factors involved. A good option to overcome this problem is the application of the response surface methodology (RSM). This optimization method is largely used to define the relation between the response and the independent variables. This tool can be applied to develop new products and processes, to improve products and methodologies, to optimize manufacturing processes and to minimize production cost. ${ }^{21}$

Souza et al. ${ }^{22}$ used RSM to optimize the saponification conditions to extract and determine tocopherols contents in peanut samples. A $2^{2}$ experimental planning was used to investigate the influence of two factors (concentrations of azuki and chia flour) on the fatty acid composition of chocolate cake..$^{23}$ Rodrigues et al..$^{24}$ studied the effect of genotype and roasting conditions on the fatty acid composition of peanut samples with a $3^{2}$ factorial design.

The objective of this study was to propose an alternative for the reuse of lactose contained in powdered whey permeate by optimizing isomerization methodology for the production of lactulose, thus avoiding the disposal of this polluting by-product in the environment. In this way, the influence of two variables were evaluated: isomerizing type and reaction time of lactulose synthesis, in order to obtain the highest reaction yield, using RSM.

\section{Experimental}

\section{Sampling}

The powdered whey permeate was obtained from the ultrafiltration of whey to produce whey protein concentrate, followed by spray drying. This by-product was provided by a company from the western region of Paraná State, Brazil.

\section{Reagents and standards}

All reagents were of analytical purity and had different commercial origins. The reagents used for chromatographic analyses, such as acetonitrile $\left(\mathrm{CH}_{3} \mathrm{CN}\right)$, were of HPLC grade, and ultra-pure water $(18.2 \mathrm{M} \Omega \mathrm{cm}$ deionized water, with conductivity $0.054 \mu \mathrm{S} \mathrm{cm}^{-1}$ at $25^{\circ} \mathrm{C}$ ) was used. The lactulose standard used to prepare the calibration curve was purchased from Sigma-Aldrich and had a purity greater than $95 \%$.

Isomerization of lactose using sodium sulfite $\left(\mathrm{Na}_{2} \mathrm{SO}_{3}\right)$ and sodium hydroxide $(\mathrm{NaOH})$

The synthesis of lactulose from whey permeate lactose using $\mathrm{Na}_{2} \mathrm{SO}_{3}$ and $\mathrm{NaOH}$ at the concentration of $10 \%$ was based on the methodology of Ayder and Halleux ${ }^{25}$ with some adaptations. It used $44.0 \mathrm{~g}$ of whey permeate reconstituted in $100 \mathrm{~mL}$ of water, and a mass of $\mathrm{Na}_{2} \mathrm{SO}_{3}$ (analytical pure) was added according to equation 1.

Sodium sulfite mass $=\mathrm{SM} \times \% \mathrm{STS} \times \% \mathrm{SLC} \times \% \mathrm{LCF}$

where SM is the sample mass, STS the sample total solids, SLC the sample lactose content and LCF the lactose concentration factor.

The $\mathrm{pH}$ value was adjusted to 11 using a $10 \% \mathrm{NaOH}$ solution, and the samples were subjected to isomerization in a thermostatic bath (Tecnal, TE-0532) with stirring at 
$70{ }^{\circ} \mathrm{C}$, and reaction times of $30,60,90,135$ and $180 \mathrm{~min}$. After chilling, $\mathrm{NaOH}$ was removed from the reaction product using a chromatographic column with a diameter of $10 \mathrm{~mm}$ and a height of $30 \mathrm{~cm}$ packed with a cation exchange resin (Purolite SST60). The solution was precipitated with $5 \mathrm{~mL}$ of Carrez I solution (potassium ferrocyanide $\left.\left(\mathrm{K}_{4}\left[\mathrm{Fe}(\mathrm{CN})_{6}\right] \cdot 3 \mathrm{H}_{2} \mathrm{O}\right) 15 \%\left(\mathrm{~m} \mathrm{v}^{-1}\right)\right)$ and Carrez II solution (zinc sulfate $\left(\mathrm{ZnSO}_{4} \cdot 7 \mathrm{H}_{2} \mathrm{O}\right) 30 \%\left(\mathrm{~m} \mathrm{v}^{-1}\right)$ ). After $1 \mathrm{~h}$ of phase separation, it was filtered on filter paper and transferred to a $250 \mathrm{~mL}$ volumetric flask. Then, $100 \mathrm{~mL}$ of ethyl alcohol were added and the volume was adjusted to the meniscus with $\mathrm{CH}_{3} \mathrm{CN}$. The solution was then filtered through a $0.45 \mu \mathrm{m}$ Millipore filter and analyzed by ultra-high performance liquid chromatography (UHPLC).

Isomerization of lactose using boric acid $\left(\mathrm{H}_{3} \mathrm{BO}_{3}\right)$ and triethylamine $\left(\mathrm{N}\left(\mathrm{CH}_{2} \mathrm{CH}_{3}\right)_{3}\right)$

For the preparation of lactulose from whey permeate lactose using $\mathrm{H}_{3} \mathrm{BO}_{3}$ and $\mathrm{N}\left(\mathrm{CH}_{2} \mathrm{CH}_{3}\right)_{3}$, the methodology of Hicks and Parrish was followed. ${ }^{26} \mathrm{~A}$ mixture containing $44.0 \mathrm{~g}$ of whey permeate, $0.8900 \mathrm{~g}$ of $\mathrm{H}_{3} \mathrm{BO}_{3}$ and $100 \mathrm{~mL}$ of water was placed into $250 \mathrm{~mL}$ Erlenmeyer flasks and the $\mathrm{pH}$ value was corrected to 11 using $\mathrm{N}\left(\mathrm{CH}_{2} \mathrm{CH}_{3}\right)_{3}$ (analytical pure). The samples were immersed in a thermostatic bath (Tecnal, TE-0532) at $70{ }^{\circ} \mathrm{C}$, and when the samples reached the reaction temperature, $10 \mathrm{~mL}$ aliquots were collected at time intervals of 30,60,90, 135 and $180 \mathrm{~min}$. The amine was removed by a chromatographic column packed with cation exchange resin (Purolite SST60) with a diameter of $10 \mathrm{~mm}$ and a height of $30 \mathrm{~cm} . \mathrm{H}_{3} \mathrm{BO}_{3}$ was removed with methyl acetate $\left(\mathrm{C}_{3} \mathrm{H}_{6} \mathrm{O}_{2}\right)$ by drying the sample in a rotary evaporator (Fisatom 802) under reduced pressure. The sample was washed with $40 \mathrm{~mL}$ of methanol and evaporated. This process was repeated three times. The final residue was dissolved in $10 \mathrm{~mL}$ of ultra-pure water, $10 \mathrm{~mL}$ of $\mathrm{CH}_{3} \mathrm{CN}$, filtered in a $0.45 \mu \mathrm{m}$ Millipore filter and analyzed by UHPLC.

\section{Isomerization of lactose by the enzymatic method}

For the synthesis of lactulose from whey permeate using $\beta$-galactosidase enzyme, the methodology described by Adamczak et al. ${ }^{27}$ was applied, with some modifications. An amount of $44.0 \mathrm{~g}$ of whey permeate was reconstituted in $100 \mathrm{~mL}$ of water, and $2.0 \mathrm{~mL}$ of $\beta$-galactosidase enzyme (Lactase Maxilact LX 5000, DSM Globalfood, from Kluyveromyces lactis) was added. The reaction was allowed to proceed for 5, 10, 20, 30, 40, 50, 60, 90, 135 and $180 \mathrm{~min}$ at 35 to $37{ }^{\circ} \mathrm{C}$, with light stirring. At each time point, $1 \mathrm{~mL}$ aliquots were collected in Eppendorf tubes and heated at $100^{\circ} \mathrm{C}$ for $10 \mathrm{~min}$ in order to inactivate the enzyme. After cooling, each sample was centrifuged (Hettich, Rotina 420R). The resulting supernatant was filtered through a $0.45 \mu \mathrm{m}$ Millipore filter and analyzed by UHPLC.

Chromatographic conditions for lactulose quantification in whey permeate powder

Chromatographic analyses were performed in UHPLC equipment coupled to a refractive index detector (UHPLC RI, Dionex Corporation, UltiMate 3000, quaternary pump, Sunnyvale, Software Chromeleon, USA). The separation was performed on a Rezex ${ }^{\mathrm{TM}}$ RPM-monosaccharide $\mathrm{Pb}^{+2}$ (8\%) column (Phenomenex, $300 \times 7.8 \mathrm{~mm}, 0.8 \mu \mathrm{m}$ ), using ultra-pure water as the mobile phase. The flow rate was $0.40 \mathrm{~mL} \mathrm{~min}^{-1}$ and the injection volume was $20 \mu \mathrm{L}$. The retention time was $17.9 \mathrm{~min}$ for lactose and $20.3 \mathrm{~min}$ for lactulose. Peaks were identified by comparison of their retention times with lactose and lactulose standards. Quantification was performed using the external standard method. The calibration curves for each sugar were prepared using five concentration levels, from 10 to $80 \mathrm{mg} \mathrm{mL}^{-1}$ for lactose and lactulose, all dissolved in ultra-pure water. The limits of detection (LOD) and of quantification (LOQ) were estimated by triplicate analysis of standard calibration curves for lactose and lactulose, considering the signal-to-noise ratio relative to the background signal as 3 and 10 , respectively. ${ }^{28}$

\section{Experimental design}

A $3^{2}$ full factorial design (two factors at three levels) with duplicates was performed to investigate the influence of two factors on the isomerization reaction of lactose. The two factors were the time of reaction (90, 135 and $180 \mathrm{~min})$ and the type of isomerization (sodium sulfite, boric acid and enzyme), as shown in Table 1. The analyzed response was the lactulose concentration.

\section{Statistical analysis and experimental optimization}

All statistical analyses were conducted using Statistica software version 7.0 (StatSoft, USA) with a 5\% $(p<0.05)$ significance level for rejection of the null hypothesis. Initially, the values of the main effects, interactions and analysis of variance (ANOVA) were obtained. Thereafter, the normality and homogeneity of variance of all variables was assessed using residual plots. Then, analysis of variance (two-way ANOVA between groups) was performed for all responses. To evaluate the effects of independent variables on the responses, RSM was applied. The basic model equation used to fit the data was (equation 2):

$\mathrm{E}(\mathrm{y})=\beta_{0}+\beta_{1} \mathrm{x}_{1}+\beta_{2} \mathrm{x}_{2}+\beta_{12} \mathrm{x}_{1} \mathrm{x}_{2}+\beta_{11} \mathrm{x}_{11}^{2}+\beta_{22} \mathrm{x}_{22}^{2}$ 
The complete model was showing according equation 3 :

$$
\mathrm{E}(\mathrm{y})=\beta_{0}+\beta_{1} \mathrm{x}_{1}+\beta_{2} \mathrm{x}_{2}+\beta_{12} \mathrm{x}_{1} \mathrm{x}_{2}+\beta_{11} \mathrm{x}_{11}^{2}+\beta_{22} \mathrm{x}_{22}^{2}+
$$$$
\beta_{12} x_{1} x_{2}^{2}+\beta_{12} x_{1}^{2} x_{2}+\beta_{12} x_{1}^{2} x_{2}^{2}
$$

where $\mathrm{E}(\mathrm{y})$ is the expected response, $\beta_{0}$ is a constant, $\beta_{1}, \beta_{2}$, $\beta_{11}, \beta_{22}$ and $\beta_{12}$ are the regression coefficients, and $x_{1}$ and $x_{2}$ are the levels of the independent variables.22

The selection of the regression terms that compose the model equation was performed to maintain the mathematical hierarchy. First, the coefficients that correspond to the quadratic interactions were removed, then the linear interaction coefficients were removed, and finally, when necessary, the quadratic main effects were removed..$^{20}$

The optimization of the experiment consisted in obtaining a global response through the selection of some equations. The desirability function was applied with the transformation of the estimated response $\left(\mathrm{Y}_{\mathrm{i}}\right)$ to the desired value $\left(\mathrm{d}_{\mathrm{i}}\right)$, where $0 \leq \mathrm{d}_{\mathrm{i}} \leq 1$.

If the objective $\mathrm{T}$ is in the response, $\mathrm{Y}_{\mathrm{i}}$ is the maximum value (equation 3):

$d_{i}=\left\{\begin{array}{cc}0 & Y_{i}<L \\ \left(\frac{Y_{i}-L}{T-L}\right)^{r} & L \leq Y_{i} \leq T \\ 1 & Y_{i}>T\end{array}\right.$

If the objective $\mathrm{T}$ is in the response, $\mathrm{Y}_{\mathrm{i}}$ is the minimum value (equation 4):

$d_{i}=\left\{\begin{array}{cc}1 & Y_{i}<T \\ \left(\frac{U-Y_{i}}{U-T}\right)^{r} & T \leq Y_{i} \leq U \\ 0 & Y_{i}>U\end{array}\right.$

In this case, $\mathrm{L}$ is the lower limit and $\mathrm{U}$ the upper limit.

The convenience function is linear when the weight $r$ is equal to 1 . When the chosen $r>1$, there will be greater emphasis on values close to the target. If the preference is $0<\mathrm{r}<1$, it will have minor importance.

The individual desirability values $\left(\mathrm{d}_{\mathrm{i}}\right)$ were combined through a geometric mean to form a global or general convenience (D). This unique value of $\mathrm{D}(0,1)$ provides the overall assessment of combined convenience and the response levels, and $\mathrm{D}$ increases as the balance of properties becomes more favorable. ${ }^{29}$

\section{Results and Discussion}

The chromatographic conditions for lactose and lactulose quantification in whey permeate powder were available although the LOD and LOQ values. Thus, the LOD values were $1.30 \times 10^{-3}$ and $1.21 \times 10^{-3} \mathrm{mg} \mathrm{mL}^{-1}$ for lactose and lactulose, respectively. The LOQ values were $4.35 \times 10^{-3}$ and $4.02 \times 10^{-3} \mathrm{mg} \mathrm{mL}^{-1}$ for lactose and lactulose, respectively.

Table 1 presents the conditions of the $3^{2}$ full factorial model (in duplicate) applied to the tests, as well as the experimental and model-estimated values obtained for

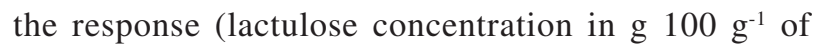
whey permeate powder). The residuals were obtained by calculating the difference between the experimental value and the value predicted by the model at each experimental point.

The main and interaction effects (linear and quadratic) were evaluated by ANOVA in order to verify their significance in the experimental model. The main quadratic effect of the time factor $\left(\mathrm{x}_{1}^{2}, p=0.2642\right)$ and the interactions $\mathrm{x}_{1} \mathrm{x}_{2}^{2}(p=0.2663)$ and $\mathrm{x}_{1}^{2} \mathrm{x}_{2}(p=0.1027)$ were not significant (Figure 1).

Initially, the $3^{2}$ full factorial design presented a coefficient of determination equal to 0.9996 and $\mathrm{R}_{\text {adjusted }}^{2}=0.9993$ (determination coefficient), which allowed a good explanation of the evaluated parameters to be obtained (time of reaction and type of isomerization). However, it was not possible to calculate the lack of fit since all degrees of freedom were compromised with the main effects and interactions (linear and quadratic). Thus, removing the non-significant effects mentioned above, it was possible to calculate the lack of fit with three degrees of freedom (non-significant effects eliminated from the model) to verify if the model with the main effects and interactions (containing linear and quadratic terms) was able to adequately explain the factors in lactulose synthesis. The withdrawal of the model terms must follow the mathematical hierarchy, the interaction terms with lower significance were removed at first, then, if necessary, the main quadratic terms were removed.

In this study, the interactions $\mathrm{x}_{1} \mathrm{x}_{2}^{2}(p=0.2663)$ and $\mathrm{x}_{1}^{2} \mathrm{X}_{2}(p=0.1027)$ were removed, this action allowed to obtain the lack of fit with two degrees of freedom (Table 3). A new Pareto graph (Figure 2) was constructed and the quadratic main effect $\mathrm{x}_{1}$ (time) remained non-significant, but it was nor removed from the model to maintain the mathematical hierarchy. In this process, it was verified that the determination coefficient (Table S1, in the Supplementary Information (SI) section) did not have a marked decrease and $\mathrm{R}_{\text {adjusted }}^{2}$ was 0.9991 . These values need to be very close, and in this study, it was possible to explain up to $99 \%$ of occurrences through these factors.

There was no lack of fit (Table 2), the residuals had a random distribution, normality and homogeneity in the 
Table 1. Parameters of the $3^{2}$ full factorial design (in duplicate) and the responses obtained in the assays

\begin{tabular}{|c|c|c|c|c|c|}
\hline \multirow[b]{2}{*}{ Assay } & \multicolumn{2}{|c|}{ Independent variable level } & \multicolumn{3}{|c|}{ Response } \\
\hline & time / min & Isomerization & $\begin{array}{c}\text { Lactulose / } \\
\text { (g } 100 \mathrm{~g}^{-1} \text { of sample) }\end{array}$ & $\begin{array}{l}\text { Predicted value }{ }^{\mathrm{a}} / \\
\left(\mathrm{g} 100 \mathrm{~g}^{-1} \text { of sample }\right)\end{array}$ & Residual $^{\mathrm{b}}$ \\
\hline 1 & 90 & sulfite & 7.44 & \multirow{2}{*}{8.00} & -0.56 \\
\hline 2 & 90 & sulfite & 7.99 & & -0.01 \\
\hline 3 & 135 & sulfite & 9.01 & \multirow{2}{*}{9.33} & -0.32 \\
\hline 4 & 135 & sulfite & 10.30 & & 0.97 \\
\hline 5 & 180 & sulfite & 8.95 & \multirow{2}{*}{8.84} & 0.11 \\
\hline 6 & 180 & sulfite & 8.65 & & -0.19 \\
\hline 7 & 90 & borate & 3.90 & \multirow{2}{*}{3.11} & 0.79 \\
\hline 8 & 90 & borate & 3.46 & & 0.35 \\
\hline 9 & 135 & borate & 4.70 & \multirow{2}{*}{5.01} & -0.31 \\
\hline 10 & 135 & borate & 4.01 & & -1.00 \\
\hline 11 & 180 & borate & 6.39 & \multirow{2}{*}{6.28} & 0.11 \\
\hline 12 & 180 & borate & 6.34 & & 0.06 \\
\hline 13 & 90 & enzyme & 43.61 & \multirow{2}{*}{44.52} & -0.91 \\
\hline 14 & 90 & enzyme & 44.86 & & 0.34 \\
\hline 15 & 135 & enzyme & 47.72 & \multirow{2}{*}{47.03} & 0.69 \\
\hline 16 & 135 & enzyme & 47.01 & & -0.02 \\
\hline 17 & 180 & enzyme & 49.80 & \multirow{2}{*}{50.10} & -0.30 \\
\hline 18 & 180 & enzyme & 50.32 & & 0.22 \\
\hline
\end{tabular}

a Predicted values of the model at each experimental point for the $3^{2}$ factorial design; ${ }^{b}$ residuals of the model.

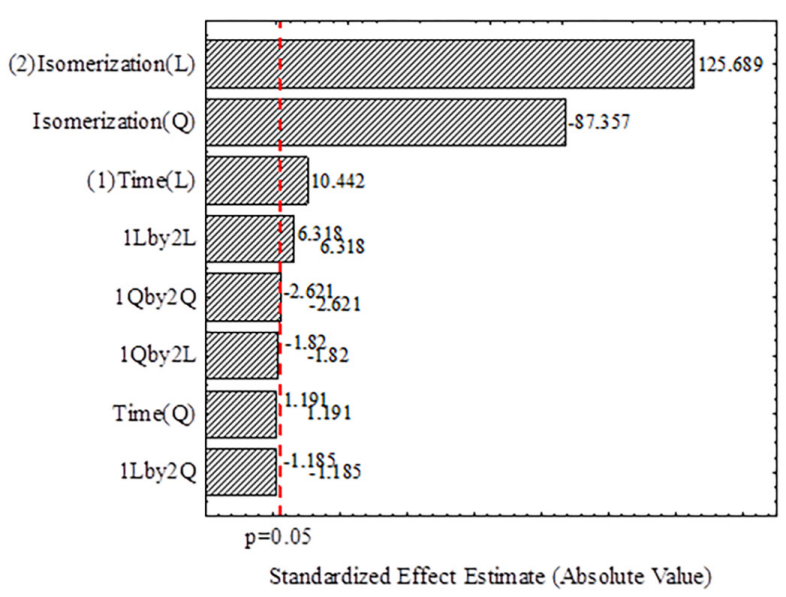

Figure 1. Pareto graphic representing the level of significance of each main effect and interaction (linear and quadratic), for the full $3^{2}$ design.

variance, and the values predicted by the model (calculated) were very close to the experimental values (Table 1). All of these factors are important to attest to the quality in obtaining responses from factorial designs. ${ }^{20}$

After removing the non-significant terms (Figure 1), it was possible to determine the model equation and their determination coefficients $\left(\mathrm{R}^{2}\right)$ as listed in Table $\mathrm{S} 1$ (in the Supplementary Information (SI) section).

The data of the independent variables and the responses were analyzed to obtain the regression equation (Table S1), as well as the values of each main effect and the interaction

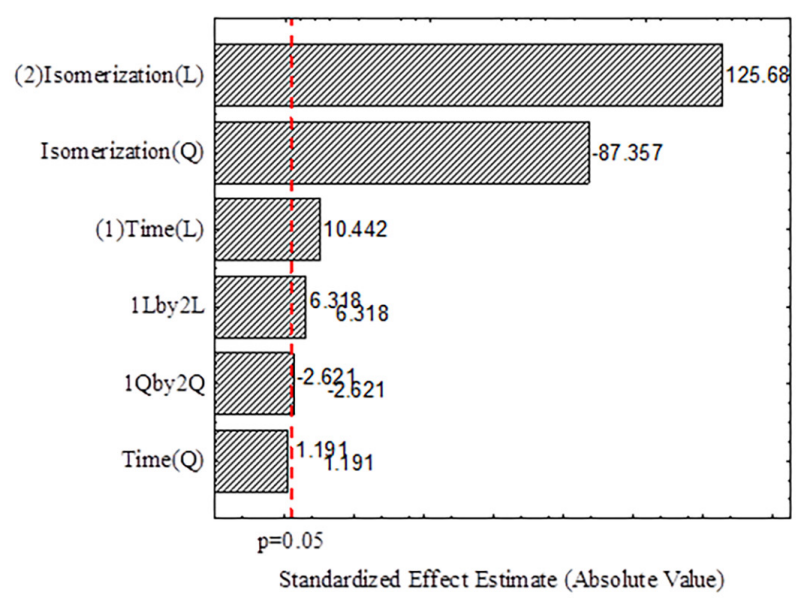

Figure 2. Pareto graphic representing the level of significance of each main effect and interaction (linear and quadratic) after remove of the non-significant effects, for the full $3^{2}$ design.

between these effects, and the contribution of these effects to the model, using ANOVA.

Table S1 shows the values of the significant main effects and their interactions for the response, and Table 2 presents the results obtained by ANOVA for the $3^{2}$ full design in duplicate for the studied response. The response surface was constructed for the levels and independent variables, as shown in Figure 3.

Table S1 and Figure 3 clearly show that the factor that contributed most to the response (concentration 
Table 2. ANOVA results for the response studied in the $3^{2}$ factorial model

\begin{tabular}{lccccc}
\hline Source & Sum of square & Degree of freedom & Mean square & $F$-test & $p$ value \\
\hline $\mathrm{x}_{1}(\mathrm{~L})$ & 30.688 & 1 & 30.688 & 109.04 & 0.000002 \\
$\mathrm{x}_{1}(\mathrm{Q})$ & 0.399 & 1 & 0.399 & 1.42 & 0.264230 \\
$\mathrm{x}_{2}(\mathrm{~L})$ & 4445.980 & 1 & 4445.980 & 15797.63 & 0.000000 \\
$\mathrm{x}_{2}(\mathrm{Q})$ & 2147.705 & 1 & 2147.705 & 7631.31 & 0.000000 \\
$\mathrm{x}_{1}(\mathrm{~L})$ by $\mathrm{x}_{2}(\mathrm{~L})$ & 11.234 & 1 & 11.234 & 39.92 & 0.000138 \\
$\mathrm{x}_{1}(\mathrm{Q})$ by $\mathrm{x}_{2}(\mathrm{Q})$ & 1.934 & 1 & 1.934 & 6.87 & 0.027749 \\
Lack of fit & 1.324 & 2 & 0.662 & 2.35 & 0.150815 \\
Pure error & 2.533 & 9 & 0.281 & - & - \\
\hline Total & 6641.796 & 17 & - & - & - \\
\hline
\end{tabular}

$\mathrm{x}_{1}$ : time; $\mathrm{x}_{2}$ : isomerization: $\mathrm{L}$ : linear term; $\mathrm{Q}$ : quadratic term.

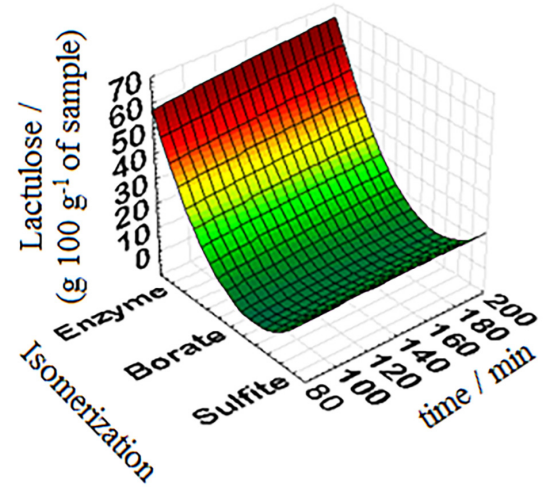

Figure 3. Response surface for the concentration of lactulose according to the type of isomerization and reaction time.

of lactulose) was the isomerization because the points corresponding to this main effect were further from zero (Table S1). It is possible to verify that the quadratic term of the isomerization type factor contributes negatively to the response, since at this level, sodium sulfite is present, which presented intermediate values in the synthesis of lactulose. The linear term obtained a greater and positive contribution to increase of the response, and it is represented by the enzymatic isomerization. Table $\mathrm{S} 1$ also shows that there is a positive contribution of the linear term of the time factor in the response, but a small one. The interaction effects among the significant factors presented a smaller contribution compared with the main effects on the response.

Therefore, the response surface (Figure 3) obtained from the $3^{2}$ full factorial design indicated that the time investigated (three levels) had little influence on the reaction, and the use of $\beta$-galactosidase enzyme provided greater efficiency in the isomerization of lactose into lactulose.

The desirability function was used to determine the best conditions for the synthesis of lactulose from whey powder lactose. The investigated factors (reaction time $\left(\mathrm{x}_{1}\right)$ and type of isomerization $\left(\mathrm{x}_{2}\right)$ ) were evaluated to obtain the highest lactulose content at the end of the process, with the convergence of the target (desirable) to the maximum value (equation 4 ).

The optimum conditions consisted of a time $\left(\mathrm{x}_{1}\right)$ of $180 \mathrm{~min}$ and isomerization $\left(\mathrm{x}_{2}\right)$ using enzyme (Figure 4). Thus, it was not necessary to perform further experiments different from those proposed by the experimental design since the best working condition was the one of the experimental points.

The best mean result was $50.06 \mathrm{~g}$ of lactulose per $100 \mathrm{~g}$ of whey powder, and the value predicted by the model

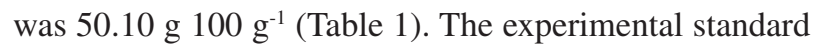
deviation was low $( \pm 0.3677)$, with a coefficient of variation of $0.7345 \%$. The difference between experimental

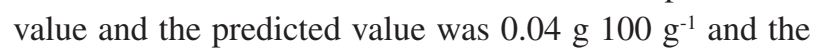
confidence interval was $46.7564(-95 \%)$ to $53.3636(95 \%)$.

\section{Conclusions}

The application of the factorial planning enabled the definition of the most adequate levels of both factors studied that produced the best response. It was possible to extract a maximum useful information from the system studied making a minimum number of experiments.

According to the response surface generated by the model, the optimum region of work, where a greater synthesis of lactulose was achieved, was throughout the time range evaluated for the reaction and the enzymatic isomerization with enzyme $\beta$-galactosidase. The desirability function indicated the best experimental conditions for lactulose synthesis, which consisted of a time $\left(\mathrm{x}_{1}\right)$ of $180 \mathrm{~min}$ and the use of enzymatic isomerization $\left(\mathrm{x}_{2}\right)$, obtaining a yield of $55.59 \%$. In the optimization process, it is important to emphasize that the optimal point or region of highest efficiency is obtained. 


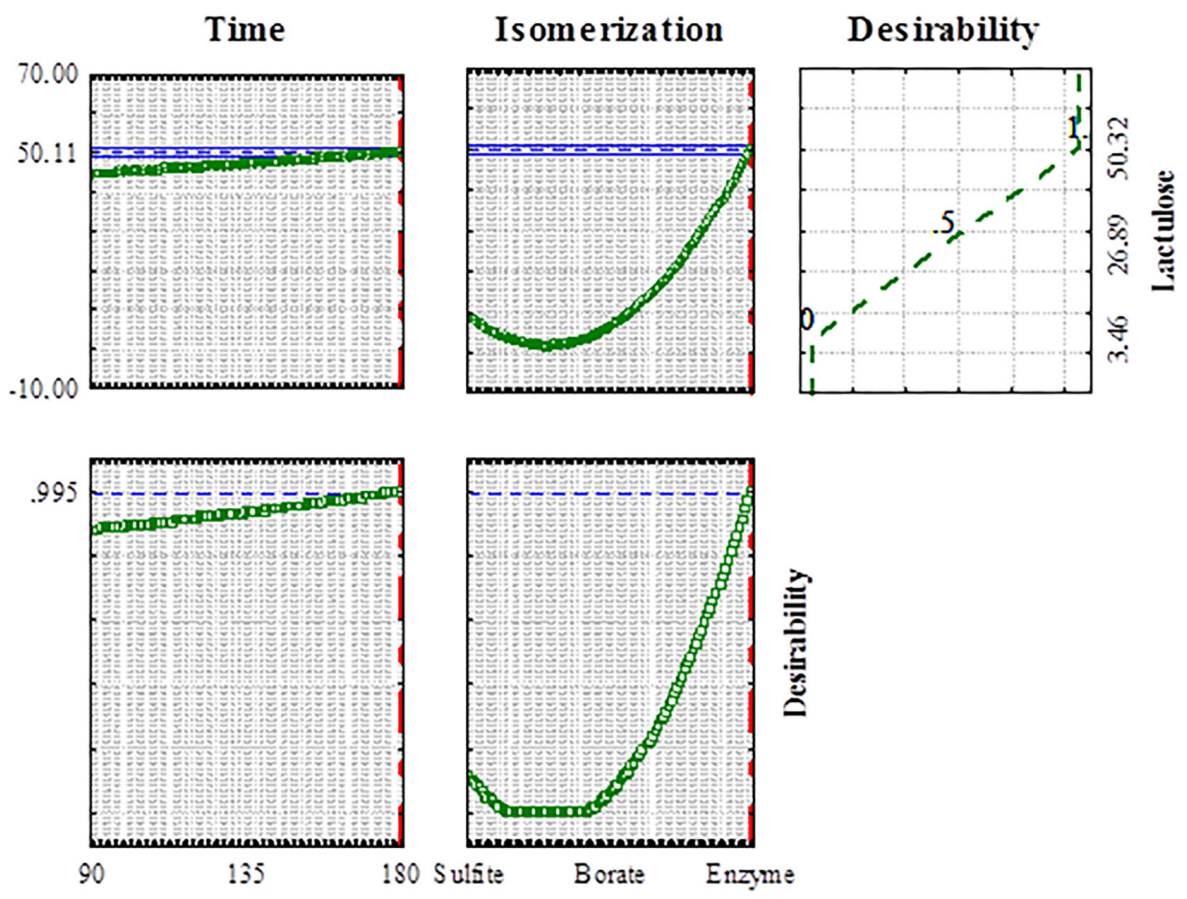

Figure 4. Graphic of the desirability function of the $3^{2}$ design for optimization of lactulose synthesis.

In the present study, the process of isomerization of whey permeate for the production of lactulose was verified. This substance has many applications in the food and pharmaceutical industry, and its production from whey is also a viable method for minimizing the environmental impact of dairy production.

\section{Supplementary Information}

Supplementary information (Table S1) is available free of charge at http://jbcs.org.br as PDF file.

\section{Acknowledgments}

The authors thank Capes, CNPq, Fundação Araucária for the financial support and for the scholarship offered; and the Universidade Tecnológica Federal do Paraná (UTFPR), Medianeira unit, for the resources and technology available for this research.

\section{References}

1. Paseephol, T.; Small, D. M.; Sherkat, F.; Food Chem. 2008, 111, 283.

2. Seki, N.; Saito, H.; Int. Dairy J. 2012, 22, 110.

3. Silva, A. N.; Perez, R.; Minim, V. P. R.; Martins, D. D. S.; Minim, L. A.; Food Res. Int. 2015, 73, 62.

4. Seo, Y. H.; Park, G. W.; Han, J. I.; Food Chem. 2015, 173, 1167.

5. Seo, Y. H.; Sung, M.; Han, J. I.; Food Chem. 2016, 197, 660.
6. Drakoularakou, A.; Rastall, R.; Gibson, G. In Functional Foods: Concept to Product - Woodhead Publishing Series in Food Science, Technology and Nutrition (205), $2^{\text {nd }}$ ed.; Saarela, M., ed.; Woodhead Publishing Ltd: Oxford, UK, 2011, p. 449.

7. Buhring, R. S. W.; Fischera, L.; Hinrichs, J.; Int. Dairy J. 2010 , $20,731$.

8. Wang, H.; Yang, R.; Hua, X.; Zhao, W.; Zhang, W.; Appl. Microbiol. Biotechnol. 2013, 97, 6167.

9. EN 575/2011: Quality and Safety of Feeds and Food for Europe; European Commission for Standardization, European Union, 2011.

10. Kassa, A.; Brownbridge, M.; Parker, B. L.; Skinner, M.; Gouli, V.; Gouli, S.; Mycol. Res. 2008, 102, 583.

11. Abboud, M. M.; Aljundi, I. H.; Khleifat, K. M.; Biochem. Eng. J. 2010, 48, 166.

12. Alonso, S.; Rendueles, M.; Diaz, M.; Bioresour. Technol. 2011, 102, 9730 .

13. Ordoñez, J. A. P.; Tecnologia de Alimentos: Componente dos Alimentos e Processos, vol. 1; Artmed: São Paulo, Brasil, 2005.

14. Pereira, J. P. F.; Rev. Inst. Laticínios Cândido Tostes 2010, 65, 26.

15. Pelegrine, D. H. G.; Carrasqueira, R. L.; Braz. J. Food Technol. 2015, 18, 3.

16. Oliveira, M. N.; Tecnologia de Produtos Lácteos Funcionais, $1^{\text {a }}$ ed.; Atheneu: São Paulo, Brasil, 2009.

17. Ziegler, F. L. F.; Sgarbieri, V. C.; Rev. Nutr. 2009, 22, 61.

18. Fox, P. F.; Mcsweeney, P. L. H.; Dairy Chemistry and Biochemistry; Thomson Science: London, UK, 1998. 
19. National Dairy Council (NDC), http://researchsubmission. nationaldairycouncil.org, accessed on May 4, 2016.

20. Neto, B. B.; Scarminio, I. S.; Bruns, R. E.; Como Fazer Experimentos: Pesquisa e Desenvolvimento na Ciência e Indústria, $2^{\mathrm{a}}$ ed.; Editora da Unicamp: Campinas, Brasil, 2001.

21. Granato, D.; Bigaski, J.; Castro, I. A.; Masson, M. L.; Food Chem. 2010, 121, 899.

22. Souza, A. H. P.; Gohara, A. K.; Rodrigues, A. C.; Stroher, G. L.; Silva, D. C.; Visentainer, J. V.; Souza, N. E.; Matsushita, M.; Food Chem. 2014, 158, 315.

23. Gohara, A. K.; Souza, A. H. P.; Rotta, E. M.; Stroher, G. L.; Gomes, S. T. M.; Visentainer, J. V.; Souza, N. E.; Matsushita, M.; J. Braz. Chem. Soc. 2016, 27, 62.
24. Rodrigues, A. C.; Ströher, G. L.; Freitas, A. R.; Visentainer, J. V.; Oliveira, C. C.; Souza, N. E.; Food Res. Int. 2011, 44, 187.

25. Ayder, M.; Halleux, D.; Trends Food Sci. Technol. 2007, 18, 356.

26. Hicks, K. B.; Parrish, F. W.; Carbohydr. Res. 1980, 82, 393.

27. Adamczak, M.; Charubin, D.; Bednarski, W.; Chem. Pap. 2009, $63,111$.

28. Analytical Methods Committee; Analyst 1987, 112, 199.

29. Derringer, G.; Suich, R.; J. Qual. Technol. 1980, 12, 214.

Submitted: March 16, 2017

Published online: May 10, 2017 